\title{
ORANG KRISTEN DAN KEHIDUPAN POLITIK
}

Tiap-tiap orang harus takluk kepada pemerintahan yang di atasnya; sebab tidak ada pemerintah, yang tidak berasal dari Allah; dan pemerintah-pemerintah yang ada ditetapkan oleh Allah.” (Roma 13:1).

\section{Hadi P. Sahardjo}

\section{ABSTRAK}

Saat ini banyak orang Kristen dibingungkan dengan berbagai isu dan peran politik yang harus dilakoninya di sekitar Pemilu-baik Pileg maupun Pilpres. Apakah orang Kristen harus hanya menyerahkan "nasib" kepada orang lain, atau harus berperan aktif dalam peran-peran dimaksud? Banyak contoh baik dari Alkitab, pribadi Yesus sendiri maupun para tokoh Kristen dan teolog yang bersinggungan baik secara langsung maupun tidak langsung dengan soal-soal politik dan kepemerintahan. Lalu orang Kristen harus berda di mana?

\section{PENDAHULUAN}

Bagi bangsa Indonesia, tahun ini merupakan tahun politik. Ada dua perhelatan besar yang digelar oleh pemerintah lewat Komisi Pemilihan Umum (KPU), yakni Pemilihan Anggota Legislatif (Pileg) dan Pemilihan Presiden (Pilpres) untuk masa tugas lima tahun ke depan. Aroma Pileg dan Pilpres telah membius hampir seluruh masyarakat Indonesia, sehingga di berbagai kesempatan dan tempat, selalu saja soal Pemilu, partai mana yang menjadi pemenang atau siapa tokoh yang layak menjadi presiden harapan bangsa. Seolah-olah semua orang telah menjadi politikus, atau setidak-tidaknya menjadi pengamat politik dadakan. Tidak jarang percakapan antara sahabat, bahkan mungkin sesama anggota keluarga bisa "memanas" akibat berbeda pendapat soal partai atau tokoh mana yang dijagokan. Tetapi banyak juga yang saling mendukung dan mengiyakan pendapat pihak lainnya. 
Pemilu Legislatif (Pileg) yang baru saja usai, nampaknya akan memberikan suasana baru dalam dinamika politik untuk lima tahun ke depan. Kita tidak tahu siapa yang nantinya akan menjadi orang nomor satu di negeri ini, karena Pilpres masih belum digelar. Partai-partai pemenang Pileg masih sibuk membangun koalisi, karena tidak ada satu pun partai yang menang mutlak. Tetapi yang pasti tahun ini Indonesia akan memiliki presiden baru, karena SBY sudah tidak mungkin mencalonkan diri dan dicalonkan lagi. Sekarang rakyat Indonesia diperhadapkan dengan sebuah pilihan yang sangat menentukan masa depan bangsa dan negara. Hanya ada dua pilihan. Mau Jokowi-Jusuf Kalla atau Prabowo-Hatta. Yang jelas siapa pun dia, apa pun ideologinya, kalau itu adalah pilihan (mayoritas) rakyat Indonesia, maka tidak ada alasan bagi orang Kristen untuk menolaknya; meskipun itu mungkin tidak sesuai dengan aspirasi kita.

\section{ORANG KRISTEN DAN SIKAPNYA TERHADAP POLITIK}

Sejak lama, dalam perjalanan sejarah bangsa Indonesia, ada tokoh-tokoh Kristen yang juga seorang politikus. Sebut saja nama-nama berikut ini. Mr. O. Notohamidjojo, T.B. Simatupang, Sam Ratulangi, dsb. Mereka itu adalah politikus, agamawan sekaligus negarawan. Itu berarti bahwa sebenarnya politik tidak tabu bagi orang Kristen.

Pada tahun 90-an ada sebuah gereja di Malang memroklamasikan dirinya sebagai gereja pendukung partai penguasa Orde Baru. Herannya, hampir seratus persen jemaatnya mendukung sikap pendeta, sampai akhirnya mereka menyadari bahwa mereka hanya diperalat oleh si Pendeta yang ternyata mencalonkan diri sebagai anggota legislatif tingkat kota, meski akhirnya gagal terpilih. Memang gereja itu pada awalnya mendapat banyak dukungan dan sumbangan dari pemerintah, termasuk membangun gedung pastori. Tapi lama kelamaan gereja tersebut menjadi sepi karena banyak jemaat yang mundur setelah tahu bahwa mereka telah dimanfaatkan oleh pendetanya. Hal yang sama terjadi di beberapa tempat di Papua, ketika pendeta, majelis dan 
beberapa jemaat menjadi pendukung dan nyaleg dari beberapa partai yang berbeda, termasuk dari partai yang berbasis agama tertentu. Dalam hal seperti ini sebaiknya seorang hamba Tuhan memang tidak boleh melibatkan diri dalam politik praktis. Biarkan jemaat awam yang menjadi politikus yang jujur dan benar serta demi kepentingan bangsa, negara dan bagi kemuliaan-Nya.

\section{Sikap terhadap Pemerintah}

Adalah suatu keharusan bagi orang Kristen untuk mengakui bahwa pemerintah sebagai sebuah institusi pada hakikatnya adalah benar, dan para penguasa adalah pelayan-pelayan Allah (Roma 13:1-7). Demikian pula adalah tugas bagi orang Kristen untuk mematuhi atau menaati negara, di mana mereka menjadi warga negaranya. Dalam hal ini rasul Petrus mengatakan, "Tunduklah, karena Allah, kepada semua lembaga manusia, baik kepada raja sebagai pemegang kekuasaan yang tertinggi, maupun kepada wali-wali yang diutusnya untuk menghukum orang-orang yang berbuat jahat dan menghormati orang-orang yang berbuat baik." (1 Petrus 2:13-14). Oleh karena kesadaran bahwa pemerintah itu adalah wakil Allah, maka orang Kristen juga harus menunjukkan kesetiaan kepada Allah dengan menundukkan dirinya kepada pemerintahan manusia. ${ }^{1}$ Karena negara adalah sebuah institusi yang didirikan Allah sendiri, maka tidak ada alasan bagi orang Kristen untuk tidak menghargainya, apa pun bentuknya. Tentu saja hal ini sangat jauh berbeda dengan pandangan Marxisme/Leninisme, sebagaimana dikatakan oleh Frederick Engels, "Dalam kenyataannya, negara adalah tidak lebih daripada sebuah mesin yang menekan satu kelas ke kelas yang lain." 2

\section{Politik Kerajaan Allah}

Bukankah ini suatu perpaduan pemikiran yang konyol? Apakah Alkitab berbicara soal politik, atau sebaliknya malah menabukannya? Pertanyaanpertanyaan semacam ini layak dikemukakan, karena pada umumnya kita

${ }^{1}$ David A. Noebel, Peperangan untuk. Kebenaran (Jakarta: YWAM Publishing Indonesia, 2004), 339.

${ }^{2}$ Ibid, 323. 
sebagai orang Kristen memang berpegang bahwa Alkitab adalah buku suci, firman Allah sendiri. Dengan kata lain kita pasti akan mengatakan bahwa Alkitab hanya berbicara soal-soal rohani, soal surga dan keakanan. Tetapi pasti tidak berbicara tentang politik.

Tetapi sebenarnya ketika kita berbicara tentang "kerajaan" menurut Malcolm Brownlee, maka kita sebenarnya sedang menggunakan bahasa dan istilah politik. ${ }^{3}$ Begitu pun ketika di dalam Alkitab, khususnya kitab Injil, disebutkan tentang Kerajaan Surga (Matius 3:2; 4:17; 5:3, 10 dan sebagainya) serta Kerajaan Allah (Lukas). Penyebutan ini tentunya juga memiliki makna khusus. Allahlah pemilik dan penguasa atas segala pemerintahan, baik yang di atas maupun yang ada di bumi. Ini tentu tidak semata-mata berbicara tentang politik, atau tentang agama, tetapi soal pemilik dan pemegang kuasa yang sebenarnya. Kerajaan Allah hanya bisa diberi dan diambil oleh Allah, dan kita hanya bisa memilih untuk memasuki dan menerimanya (Matius 21:43; Lukas 12:32). Kita pun dapat mewarisi, memilikinya, atau bahkan menolak untuk memasukinya. ${ }^{4}$ Ketika Tuhan Yesus diutus oleh Bapa—sebagai Raja Penguasa, khalik langit dan bumi-untuk datang ke dalam dunia ini, maka Dia juga akan membangun Kerajaan Allah di bumi. Namun kerajaan yang dibangun-Nya bukanlah kerajaan atau pemerintahan sebagaimana konsep dunia. Karena Kerajaan Allah adalah untuk "mempersatukan di dalam Kristus sebagai Kepala segala sesuatu, baik yang di surga maupun yang di bumi" (Efesus 1:10; 1 Korintus 15:28; Wahyu 11:15). Lebih lanjut Malcolm Brownlee menandaskan bahwa yang dimaksud dengan "kerajaan" itu bukanlah sebuah tempat atau negara yang diperintahi, melainkan lebih menunjuk pada pemerintahan atau kedaulatan. 5 Jadi memang salah besar kalau sampai akhirnya Yesus dianggap sebagai rival yang akan merebut atau menduduki

${ }^{3}$ Malcolm Brownlee, Tugas Manusia dalam Dunia Milik Tuban (Jakarta: BPK Gunung Mulia, 2011), 57.

${ }^{4}$ David F. Wells. Mengatasi Segala Kuasa Dunia: Kristus di Dalam Dunia Modern (Surabaya: Penerbit Momentum, 2013), 250.

5 Ibid, 54. 
takhta dunia_sebagaimana yang ditakutkan oleh Herodes sehingga ia berambisi untuk membunuhnya_-sebagaimana digambarkan dalam Injil Lukas pasal 2. Atau bahkan juga oleh para murid sehingga mereka berebut kedudukan, sebagaimana yang dilakukan oleh Yakobus dan Yohanes (Markus 10:35-45, lihat juga Matius 20:20-28). Otoritas yang dimiliki oleh Tuhan Yesus bukanlah otoritas yang diberikan dan dimiliki oleh dunia, karena Dia berasal dari atas. Peter O’Brien dalam tafsiran surat Efesus mengatakan demikian:

... para tuan, bertanggung jawab pada Dia yang bukan hanya Tuan mereka di surga, tetapi juga Tuan dan Tuhan dari para hamba. Intinya, semua bertanggung jawab kepada Dia. Ia berdiam di surga tempat Allah berada, dan tidak memandang muka, tetapi Ia akan memberi balasan kepada para tuan yang saleh dan taat di hari terakhir untuk semua perbuatan baik yang telah mereka lakukan kepada para hamba mereka (Efesus 5: 8, 9). Ketuhanan Kristus atas kehidupan para hamba dan tuan berdampak pada dinamika hubungan di antara keduanya dan mengangkat sikap dan perilaku mereka ke tataran yang baru. ${ }^{6}$

\section{Pandangan John Calvin terhadap Politik}

Salah seorang tokoh dalam sejarah kekristenan, John Calvin, sangat peduli soal pemerintahan sipil (dunia) ini. David Hall, salah seorang editor buku "Penuntun ke Dalam Teologi Institutes Calvin" menyebutkan bahwa John Calvin meruntut satu-persatu kewajiban warga Kristen, yang dimulai dengan seruan agar orang Kristen menghormati jabatan yang didirikan oleh Allah sebagai kewajiban yang pertama. Yang kedua, warga juga harus membuktikan ketaatan dalam hal membayar pajak, menaati pengumumanpengumuman atau peraturan-peraturan serta melayani untuk melindungi bangsa. Ketiga, Calvin juga memeringatkan agar orang Kristen tidak mencampuri secara berlebihan ke dalam otoritas megistrat sepanjang ia menghormati jabatan tersebut. ${ }^{7}$

${ }^{6}$ Peter T. O’Brien, Surat Efesus (Surabaya, Penerbit Momentum: 2013), 556.

${ }^{7}$ David W. Hall dan Peter A. Lillback, Penuntun ke Dalam Teologi Institutes Calvin (Surabaya: Penerbit Momentum, 2009), 484. 
Untuk itu Calvin memberikan catatan khusus, terkait kewajiban orang Kristen terhadap pemerintah, khususnya dalam hal membayar pajak. Ia merekomendasikan batas-batas yang bijaksana, dan berpendapat bahwa pajakpajak seharusnya hanya mendukung keperluan publik; karena menurutnya, membebankan pajak-pajak atas rakyat biasa tanpa sebab adalah suatu pemerasan tiranis. ${ }^{8}$ Memang apa yang dikatakan oleh Calvin tentunya beralasan, karena pada masanya sudah banyak pejabat pemerintah yang korup, hidup berfoya-foya, sementara banyak rakyat yang hidup dalam kekurangan.

Oleh karena itu pada sisi yang lain Calvin bahkan menyetujui atau menganggap pantas terjadinya "perlawanan" pada kondisi tertentu. Misalnya seorang tiran yang melakukan tindakan-tindakan yang sudah melampaui batasbatas yang telah ditetapkan oleh Allah; atau seorang tiran yang dalam bertindak berkontradiksi dengan suatu mandat ilahi yang lain; atau pun para magistrat ${ }^{9}$ yang lebih rendah membawakan koreksi konstitusional. ${ }^{10}$

Mungkin ini juga menjadi pertanyaan kita pada saat ini, apakah perlu orang Kristen memberikan pajak kepada pemerintah, kalau ternyata pemerintahan (pejabatnya) banyak yang korup? Memang antara membayar pajak dengan perbuatan korupsi adalah dua hal yang berbeda. Yang pertama berkaitan dengan sebuah kewajiban, sementara yang kedua berkaitan dengan soal karakter. Tetapi andaikata orang Kristen tidak membayar pajak, atau katakanlah membayar tetapi dimanipulasi (baca: tidak membayar sebagaimana mestinya), dengan alasan "takut nanti dikorupsi," bukankah sebenarnya dia sudah memulainya dengan korupsi terlebih dulu?

\section{PERLUNYA PEMERINTAHAN DUNIA}

Menurut kerangka berpikir Kristen yang alkitabiah, pemerintahan manusia dilembagakan oleh Allah untuk melindungi hak-hak manusia dari kecenderungan manusia yang berdosa. Untuk itulah maka Allah "mengizinkan" adanya pemerintahan dunia. Sekarang ini Allah bahkan

\footnotetext{
8 Ibid, 382.

${ }^{9}$ Magistrat adalah hakim atau pejabat pada pengadilan yang lebih rendah ${ }^{10}$ Ibid, 486.
} 
"merelakan" dan "melepaskan" hak pemerintahan Teokrasinya ke dalam pemerintahan sekular. Allah memakai manusia untuk menjalankan pemerintahan-Nya di dunia ini. Oleh karena itu sebagai pelaku pemerintahan Allah di dunia, maka setiap orang yang diberikan mandat oleh Allah melalui umat-Nya untuk menjadi pemimpin suatu negara, harus tunduk dan menjalankan kepemimpinannya dengan takut dan hormat kepada Allah. Kepemimpinannya adalah representasi kehadiran Tuhan atas umat-Nya. Itulah sebabnya maka ada presiden, raja atau kaisar. Mereka ini tidak berlaku sewenang-wenang, mencari keuntungan sendiri dan menindas orang lain atau rakyat yang dipimpinnya. Mereka itu dipilih oleh rakyat.

James Madison, dalam tulisannya The Federalists Paper mengatakan demikian, "Jika manusia adalah malaikat, maka pemerintah tidak diperlukan. Jika malaikat-malaikat diperintah oleh manusia, kontrol baik eksternal maupun internal pada pemerintahan sangat diperlukan."11 Di satu sisi hal ini hendak menekankan, bahwa pemerintah di dunia ini adalah sebuah keniscayaan. Tidak boleh tidak harus ada, karena manusia memang membutuhkan pemerintah. Perlu ada yang mengatur. Sementara di sisi lainnya, manusia memerintah malaikat adalah sebuah kemustahilan. Kecuali nanti kita sudah hidup dalam kemuliaan Bapa di surga. Malaikat tidak bisa bertindak atas kehendaknya sendiri, kecuali diperintah oleh Allah. Mereka melakukan segala sesuatu atas kehendak dan seizin Allah. Tetapi manusia kalau sudah berkuasa seringkali lupa siapa dirinya. Lupa pada janji-janjinya.

\section{Vox Pupuli Vox Dei}

Adagium Vox Populi Vox Dei, sangat sering diucapkan oleh para politisi maupun pakar hukum kita, lihat saja misalnya dalam acara Indonesia Lawyer Club yang dikomandoi oleh bang Karni. Masalahnya adalah, apakah makna ungkapan tersebut yang berarti "Suara Rakyat, Suara Tuhan" itu apakah sudah tepat pakai.

${ }^{11}$ James Madison, The Federalists Paper, no. 51 (New York: Pocket Books, 1964), 
Ungkapan "Vox Populi Vox Dei” ini biasanya memang dipercaya secara mentah-mentah bahwa suara rakyat adalah suara Tuhan. Dengan demikian tersirat bahwa pendapat umum selalu benar. Padahal, Vox Populi belum tentu Vox Dei. Tuhan bisa menetapkan, memimpin secara negatif, mengizinkan, dan juga membiarkan rakyat memilih sesuai dengan free will, kehendak bebasnya yang jujur-adil, langsung, bebas dan rahasia. Rakyat pemilih ini harus memilih dengan hikmat yang dari atas. Pikirkan dan pertimbangkan dari segala sesuatunya. Jangan asal pilih.

Mari kita mengambil contoh dari Jerman. Pada saat mayoritas Republik Weimar terpukau pada seorang orator ulung, maka Tuhan membiarkan munculnya Adolf Hitler. Celakanya, gereja Katolik pun bungkam terhadap holocaust Nazi. Sehingga tidak mengherankan kalau sebagian rakyat Jerman saat ini masih sangat "trauma" terhadap segala sesuatu yang berbau Nazi.

Di ambang Pilpres pada tanggal 9 Juli nanti, jauh-jauh hari sebelumnya relasi masyarakat pemilih sudah diobstruksi oleh dua pasangan, PrabowoHatta dan Jokowi-JK dengan kelebihan dan kekurangan masing-masing. Tak jarang dua orang sahabat bisa bersitegang gara-gara mendukung pasangan capres-cawapres yang berbeda. Tetapi itulah dinamika politik kita yang penuh dengan intrik dan taktik untuk bisa menjegal dan menjatuhkan lawan. Termasuk di antaranya adalah black campaign dan negative campaign dengan segala bentuknya. Lembaga riset pun bisa diperalat dan dimanipulasi untuk kepentingan salah satu pasangan calon. Kerawanan di TPS, penghitungan surat suara, penggelembungan suara, pengadministrasian dan distribusi logistik perangkat pemilu, bahkan daftar pemilih tetap (DPT) daan lain-lain bisa dimanipulasi sebegitu rupa sehingga menimbulkan berbagai krisis dan kerawan terhadap persatuan dan kesatuan bangsa Indonesia. Seharusnya setiap warga negara dan para kandidat bisa mawas diri dan kembali kepada moral hakiki jiwa kesatria untuk tidak menghalalkan segala cara.

Oleh karena itu pertanyaan yang muncul adalah, di mana Vox Dei itu ketika pemungutan suara berlangsung? Benarkah Vox Populi adalah Vox Dei, 
kalau kenyataannya yang terjadi justru Vox Doi ${ }^{12}$ atau bahkan Vox Satan? Mengapa kecurangan selalu saja terjadi dalam setiap kali Pemilu (baik Pileg maupun Pilpres), bahkan Pilkada sekalipun? Jawabannya ternyata memang bukan Vox Populi_suara rakyat_yang benar-benar memilih calon pemimpin mereka karena Vox Dei, tapi semata-mata karena kurang tahu, tidak tahu atau Vox Doi (suara karena ada duit) tadi.

Bukankah Tuhan Yesus disalibkan juga karena hanya karena Vox Populi-suara rakyat yang dimotori para pemimpin agama, ahli-ahli Taurat dan orang-orang Farisi-yang sudah terlanjur benci dengan pribadi Yesus, di samping memang ada unsur Vox Doinya (seperti halnya Yudas).

\section{TUHAN YESUS DAN POLITIK}

Untuk mengaitkan Tuhan Yesus dengan soal politik sepertinya sangat absurd. Karena kedatangan Tuhan Yesus ke dalam dunia ini bukanlah untuk misi duniawi, tapi surgawi. Semarak proklamasi Yohanes Pembaptis tentang kedatangan Tuhan Yesus, Sang Mesias, begitu menggema bagaikan kampanye pemenangan seorang capres. Ketika berkhotbah di tepi Sungai Yordan, dia menyerukan tentang pertobatan, dengan mengutip nubuatan nabi Yesaya,

Ada suara yang berseru-seru di padang gurun: Persiapkanlah jalan untuk Tuhan, luruskanlah jalan bagi-Nya. Setiap lembah akan ditimbun dan setiap gunung dan bukit akan menjadi rata, yang berliku-liku akan diluruskan, yang berlekuk-lekuk akan diratakan, dan semua orang akan melihat keselamatan yang dari Tuhan. ${ }^{13}$

Bisa dibayangkan bagaimana orang-orang yang berada di sekitar Yohanes Pembaptis itu mendengarkan dia berpidato, mirip kampanye bagi seorang capres. Dalam Injil Yohanes, dengan gaya yang lebih santun namun tetap tegas Yohanes Pembaptis-sambil menunjuk Yesus yang kala itu sedang

12 Orang dari Sulawesi, khususnya Sulawesi Utara biasa menyebut uang dengan "doi"

${ }^{13}$ Lukas 3:4-6, bdk. Yesaya 40:3-5. 
berjalan di tepi sungai Yordan-mengatakan, "Lihatlah Anak domba Allah, yang menghapus dosa dunia.” (Yohanes 1:29).

Di sini Yohanes Pembaptis sedang menunjuk pada seorang tokoh, pribadi yang sebetulnya memang sudah lama ditunggu-tunggu oleh bangsa Israel yang diharapkan akan bisa menjadi seorang pemimpin bagi mereka dan pembebas dari tekanan bangsa asing. Tak heran kalau sampai menjelang akhir perjalanan hidup Tuhan Yesus di dalam dunia ini mereka masih belum menyadari benar tentang misi-Nya yang sesungguhnya. Sehingga mereka masih mengelu-elukan-Nya dengan sorak-sorai gegap-gempita, "Hosana bagi Anak Daud, diberkatilah Dia yang datang dalam nama Tuhan, hosana di tempat yang mahatinggi!" (Matius 21:9). Tapi mereka kecele, karena Tuhan Yesus bukanlah tipikal pemimpin yang mereka harapkan, yang memiliki seabreg agenda dan ambisi kekuasaan sebagaimana pemimpin-pemimpin dunia ini, karena "Kamu berasal dari bawah, Aku dari atas; kamu dari dunia ini, Aku bukan dari dunia ini (Yohanes 8:23), dan lagi, "Kerajaan-Ku bukan dari dunia ini; jika Kerajaan-Ku dari dunia ini, pasti hamba-hamba-Ku telah melawan, supaya Aku jangan diserahkan kepada orang Yahudi, akan tetapi Kerajaan-Ku bukan dari sini." (Yohanes 18:36).

\section{Sikap Yesus terhadap Penguasa}

Sikap dan posisi Yesus selama hidup di dalam dunia ini, baik dalam sistem pemerintahan maupun dunia perpolitikan sangat jelas. Kelihatannya selalu berseberangan dengan pihak atau kelompok mana pun. Dia selalu berbeda pendapat. Sepanjang catatan keempat kitab Injil, tidak bisa ditemui satu ayat pun yang menunjukkan sikap-Nya yang sejalan dengan para pejabat pemerintah, tokoh-tokoh agama maupun para pilitikus Yahudi. Hampir selalu berbeda pendapat. Lihat saja bagaimana sikap-Nya waktu menghadapi orangorang Farisi; ahli-ahli Taurat; para Saduki, maupun pejabat pemerintahbahkan sampai pada saat penghakiman menjelang penyaliban-Nya. Satusatunya percakapan yang disambut baik oleh mereka barangkali hanya ketika 
Dia diajak ke Yerusalem pada usia 12 tahun selaku 'anak Taurat” (Bar Thoraa). Para alim-ulama atau pemimpin agama bisa terlibat dalam diskusi hangat dan sangat menarik dengan seorang bocah selama tiga hari non stop di Bait Allah. Mereka sangat heran dan memuji kecerdasan yang dimiliki-Nya (Lukas 3:4152). Tetapi di lain pihak, Tuhan Yesus juga menunjukkan otoritas dan kuasaNya ketika berhadapan dengan para ahli Taurat dan orang-orang Farisi dengan cara menghardik, menegur dan memermalukan (Matius 23) maupun dengan para penguasa (Matius 26; 27; Markus 14:53-65; 15:1-15; Lukas 23:1-5, 13-25; Yohanes 18:28-19:16) dan sebagainya.

\section{PENUTUP}

Orang Kristen yang hidup di tengah lautan politik mau tidak mau harus memiliki kepedulian terhadapnya. Bukan menarik diri atau bersikap acuh-tak acuh. Bukan pula harus terjun langsung ke khasanah politik. Biarlah itu menjadi bagian dari mereka-mereka yang memang terpanggil dan memiliki kemampuan untuk berurusan langsung dengan politik, politik praktis sebagai politikus. Jangan pula alergi terhadap semua yang berbau politik. Tetapi dengan menempatkan diri secara tepat dan menjadi warga negara yang baik dengan jalan berpartisipasi secara aktif dalam Pemilu, itu adalah sikap yang bijak. Karena "nasib" dan masa depan bangsa dan negara ini antara lain jiuga berada di tangan kita. Wujudkan negeri ini sebagai bentuk kehadiran Kerajaan Allah di dalam negeri kita.

HADI P. SAHARDJO menyelesaikan pendidikan teologinya dari SAAT, Malang (B.Th., S.Th., M.A. dan M.Div.) dan M.Th. (ITS, Los Angeles, USA) serta D.Th. (STBI Semarang). Sarjana Pendidikan (Drs.) di bidang Psikologi Pendidikan dan Bimbingan Konseling dari IKIP (sekarang Universitas) Negeri Malang. Sekarang menjadi dosen tetap di ST'T SAPPI. 